\title{
グローバル・ノースの「夜」と音楽： 夜の時間-空間を多角的に捉える
}

\section{趣旨説明 \\ グローバル・ノースの「夜」と音楽：都市と自然の二} 項対立を超えて

池田真利子（筑波大学）

2010 年代は, グローバル・ノースの都市において 「夜」への関心が高まった時期である。とりわけ，脱 工業化した西ヨーロッパの都市行政は，観光振興や 「創造性」をコンセプトとする活性化とも親和性の高 いナイトライフ観光や夜の経済的潜在力に関心を寄 せ，都市交通の 24 時間化を含む夜間モビリティの向上 を段階的に促してきた。こうした夜の時間一空間は, 民間企業や行政のみならず，学術界においても2010年 代以降注目されてきた．特に，ユトレヒト大学（オラ ンダ）の人文地理学者van Liempt氏により企画された Urban Studiesの特集号「Geographies of Urban Night (都市の夜に関する地理学)」では, 実証と理論からな る計 13 編の論文が発表され，夜を巡る多角的な研究 アプローチを整理することで, 議論の土台を構築し た。その端緒となったのは,「あらゆる学術分野にお いて自明視されてきた時間一空間は昼なのではない か」というシンプルな問いかけである.

この新しい「問い」を, 事例・地域報告を踏まえつ つ州納的に捉えるため, 2018年 4 月以降, 若手地理学 者有志で研究グループを企画し, 議論を続けてきた. その結果, 都市・自然地域の双方に共通するものとし て，夜に可視化される観光資源があること，そして人 間の身体的感覚が環境の変化により変わらざるを得な い夜の時間では視覚に代わる感覚が重要となること, であるからこそ夜の行動ではストーリーテラーやガイ ドが求められること, 夜の「光」は啓蒙として, 同様 に「闇」は反啓蒙としての側面を有すること，また フィールド調査においては工夫が必要となること等の 知見が明らかとなった，また，世界的に「夜」が非日 常で理解されるのに対し，日本における「24時間」 は日常で理解されること, また日本には,「盛り場」
と「ナイトライフ街区」が別々に存在する可能性があ ること等, 日本の夜の時間と空間の特徵も見えてきた.

本シンポジウムでは, 都市と自然双方の物理的環境 において公平に訪れる「夜」の時間一空間を多角的に 捉えるため, 空間性を創造する側面を有する「音楽」 を切り口に, シンポジウム前半は理論的研究 (池田) · 地域研究 (坂本) および空間情報 (杉本) の3 件の日 本語発表を基に議論を行った。 また後半には，前述の 夜の地理学の先駆的研究を発表したvan Liempt氏とレ スター大学（イギリス）の文化社会学者Morgner氏を 迎え, ライプチヒ大学 (ドイツ) の経済地理学者 Lange氏のキーノートレクチャーを基に, 英語での議 論を行った.

なお, SARS-CoV-2の世界的拡大により対面接触回 避の状況が続く中, 音楽を商品として扱う空間の存続 は極めて厳しい. とりわけ大都市の夜の空間は, 特定 の行動と結び付けられて理解され, 否定的に報道され る. 他方で, オンラインにより人間の行動の時間一空 間が拡張されたことで, 音楽の消費の在り方は変化し つつあるといえる. 本シンポジウムでは, こうした現 在の世界を取り巻く夜と音楽の現況を契機に, 学術界 に求められる社会的責務を捉え直すため, 座長および コメンテーターに民間企業関係者に登壇して頂いた。

\section{研究発表}

グローバル・ノースの音楽：「物質的制約」を超える 電子音楽の現状と可能性

池田真利子ほか（筑波大学）

全世界的なSARS-CoV-2の流行により, 三密を回避 することの難しい夜間音楽経済は極めて困難な状況に 置かれる.とりわけ非一物質として建物や占有領域を 超えて拡大する傾向にある音楽／音は, 都市域では騒 音問題をはじめとして規制の対象となる，本研究で は，まず，ヨーロッパの「夜間経済」がどのような社 会的背景により創出されてきたのかを，ローマ（1970 
年代)、ロンドン（1980～1990年代)，フランス（1990 年代および2010年代前半) の都市政策に注目し概観し た。本では，東京五輪開催決定直前に，かねてょり 見直しが求められていた風営法改正に向けた動きが活 発化し，またそれと歩調を合わせるように，インバウ ンド観光政策と結び付けられ，政治家を中心に「夜間 経済/ナイトタイムエコノミー」の重要性が訴えられ た。しかし，「夜間経済」の生産的側面は看過される 傾向にある，本報告では，音楽の生産一消費を再考す ることで夜間経済の意味を再考し，また，空間性を巡 る学術的議論を音楽から構築することを目的とした． な押，共同発表者の 2 名（田中・小竹）は，広義の夜 間音楽経済における地理情報をままた1名（Assfa） には夜間経済を巡る政策に関する知見を提供した，夜 間音楽経済は，法律的規制の強化を背景とし，自律的 に夜のガバナンスを促す社会組織を 2000 年代以降に 発展させてきたべルリン市のClubcomissionは, COVID-19による危機的状況に対応するため, 早期にオン ラインライブ空間整備等を行った他方で日本では，東 京を含む大都市や地方都市の夜間音楽経済は活動自肃 を行う一方で，自然公園やスキーリゾート等で密やか に音楽が継続する状況が続く．COVID-19による影響 が夜間音楽経済にどの程度現れるのか，今後は定性的 調查に次ぎ，この点に関する定量的調查が求められる といえよう。

\section{ウィンターリゾートにおけるインバウンド観光客と夜 間経済の現状一長野県白馬村の音楽空間に注目して一 坂本優紀 (西武文理大学) · 池田真利子（筑波大学）}

日本ではインバウンド観光客の増加に伴い, 新たな 観光消費の時間帯としての夜に注目が集まってきた. しかし，インバウンド観光客の訪問地には偏りがみら れ，ことさら夜間带の観光対象に関してはその傾向が 顕著である，夜間経済に関する地方部と都市部の格差 を埋めていくことが期待されることから，本報告では 日本屈指のウィンターリゾートである長野県白馬村の 事例を基に，地方部に打ける夜間経済の実態をインバ ウンド観光客の動向とともに明らかにした.

白馬村のインバウンド観光客の約 $61 \%$ はオースト ラリア人であり，その多くが冬季に来村する。 ウィン
タースポーツを楽しむ欧米系のインバウンド観光客に 顕著な観光形態として，アプレスキーと呼ばれるス キー後のアクティビティがある，彼らは食事なしの宿 泊形態かつ長期滞在するため, 外で夕食をとることが 多い。これは, 日本人観光客やアジア系のインバウン ド観光客とは異なる傾向で, 地域の夜間経済へ多大な 影響を与えるアクターとなっている。そそのため，長野 オリンピック以降，衰退傾向にあった夜間経済も，イ ンバウンド観光客の増加に伴い新たな活況がみられ る.

一方，インバウンド観光客の夜間活動においては多 数のトラブルも発生している．たとえば，深夜の騒音 問題や帰宅途中でのごみの不法投棄がある。また, 2020年 3 月にはオーストラリア企業が実施した村内で の音楽イベントが多数の問題を引き起こした。こうし た事例は，インバウンド観光客が村を消費空間として 利用する一方，村民にとっては居住空間であり，また 観光関連産業従事者にとってはサービスの生産空間と いった多様な利用が，夜間に特徽的に分化するためと 考えられる。

以上より，白馬村における夜間経済は季節性インバ ウンド観光客に依存していることが明らかとなった. こうした，季節性観光形態が卓越する地域では恒常的 な店舗運営が難しく，通年での集客に向けた新たな取 組みが必要となる。他方，トラブルが夜間の観光を抑 制しないよう，ルールの明確化や規制作りが必要と なってくるかもしれない，今後は，民間企業関係者と 協力しながら，こうした地域への新たな提案を模索し ていきたい。

\section{基調講演}

ライブ・エンターテイメント事象の時空間特性に関す る研究一全国のイベント時空間データベースの活用一 杉本興運（東洋大学）

ライブ・エンターテイメント（以下, LE）は, そ の場限りという「一回性」をもち，参加者に特別感の ある体験を提供できるという点から需要が大きく，デ ジタル化されたコンテンツが大量に流通する現代社会 にあっても，コロナ禍発生前までその市場規模は増加 していた。 また，昨今のインバウンド振興による外需 獲得策としての夜間経済活性化において，夜間経済の 
コア業種の一つにあたる産業として期待されていた。 しかし，2020年初頭でのコロナ禍発生によって，LE 産業は大きな打撃を受けたことで，訪日外国人だけで なく日本国内在住の人々をも対象とした市場の復活が 課題となっている.

本研究ではコロナ禍発生前までの LE 事象の特性を, 時間と空間の側面から明らかにした。今回は，日本全 国を対象とし，大規模なイベントデータベースの分析 を行った. これにより, 過去のLE産業の動態を理解す るとともに，今後の復興に役立つ基礎資料とすること を目指す．分析の結果, LEイベントの全体的傾向とし て18〜19時台に開演が集中していたが，ステージ部門 では13〜14時台の開演も多かった．イベント全体の約 $42 \%$ が東京都での開催であることから，東京都の夜間 にイベントが最も集中していることになる，ただし， 他のエリアについても，その多くは18～19時台の開演 であった，東京都内に焦点を当てると，時間的集中傾 向は全国と一致していた。 ただし，ジャンルを細分化 すると，イベントのジャンルによって時間的集中傾向 は大きく異なる，そして，空間的には渋谷や新宿など の商業集積地にイベント公演が集中していた。

以上より，LE事象の時間的・空間的特性を定量的 な分析で示した．LEイベントはマス市場の生活時間 に合わせて開演時間が設定されていたこと, 劇場や ホールなど集客施設の立地がLEイベントの空間分布 に強く影響していることがわかった。

今後は，平日と土日祝に分けた分析，会場規模 (うイベント規模) やイベントッアー（複数地域での公 演）を考慮した分析，LEイベントからみた地域分類 や個別地域の詳細分析を行う予定である.

\section{コメントおよび総合討論}

田中順也（(株)ナビタイムジャパン)

音楽事業者（特にクラブ経営）において，風営法お よび騷音の問題に加えてコロナの密が課題として発生 しており，民間企業からの支援も困難な状況である. 現場（アーティスト）の状況も理解していく必要があ る. その意味で長野の状況は極めて現実味があると感 じた.

TEMESGEN, Assefa.（(株)JTB 総合研究所）

日本のナイトライフ観光アメニティが依然として不
足する中，長野の事例のように日本にはまだその余地 があるように思われる。ポストコロナに向けて，コロ ナ禍で音楽業界と観光業界を接続することが課題であ り，住民や行政を巻き込んでどのように音楽を見せて いくのかが重要ではないか.

\section{八木京子（東洋大学）}

音楽と観光を結びつける動きが欧米では普及してお り，日本でもコロナ禍の前までミュージック・ツーリ ズムという形態で認知されつつあった，音楽や芸術の 役割の認識が増加しつつあり，今がパラダイムシフト の時期なのかもしれない. 同様に長野の発表も,（イ ベント企画のコンサートプロモーター時代にご本人が 携われていた）サマーソニックのように，行政や地元 住民による理解と協力と価值共創が不可欠であるよう に感じた．首都圈のライブイベントはベニューが限定 されており，使用されるスペースはイベントの場合， 狙いとするターゲットにより戦略的に変わる，今後国 や行政の助成金や企業事業体の協力が必要不可欠であ ろうと考える.

\section{INTRO}

\section{Night and Music on Global Cities}

MORGNER, Christian. (Leicester Univ.)

しばしば否定的な意味で理解される夜の肯定的側面 を探究する上で，夜の創造性の生産的側面，あるいは 共一生産的空間 co-production spacesに注目することが 重要となる．創造産業の中でも，とりわけ広義の音楽 産業は，これらに係る産業である。空間は，視覚的に 認知されるものだけではなく，人間が意味を与え，感 情を想起し，あるいは経験的に理解するものである. また，こうした空間は，消費と関連し，規制緩和の対 象となり，意味を不断に変化させる．池田と Morgnerは 文化地理学と文化社会学の学問的射程を超えて, 目下, 音楽を軸に形成される物理的空間の役割がCOVID-19 の影響を受けて変化しつつある中，夜の空間という共 通概念の検討を通して議論を構築する。そのため，本 シンポジウムでは, ドイツの経済地理学を牽引する Lange教授の Keynote Lecture ， 議論の端緒とする. 


\section{KEYNOTE LECTURE}

Music and Spaces in Global City Berlin: towards FutureOriented Geographies（グローバル都市ベルリンの音 楽と空間: その先の地理学へ)

LANGE, Bastian. (Leipzig Univ.)

本発表は，シンポジウム「グローバル・ノースの 「夜」と音楽一空間を多角的に捉える」のKeynote Lectureである. ライプチヒ大学地理学科で教授資格 を授与されたBastian Lange氏は，経済地理学（文化創 造経済）を主専門領域とし，主として 2000 年代のポス 卜社会主義のコンテクストにおけるミリュー milieu研 究を行ってきた，同氏はそこへの関心を端緒とし， ベ ルリンへの新規流入者が文化起業家となる中で, 空間 を使用してきたのかに関心をもつようになった。 ま た, 同時に, 同氏は参加型アプローチを通じて, 研究 により得られた知見を実社会に還元することを行う. 本シンポジウムでは主として, 今後に寄与すると想定 される理論の紹介，すなわち私達がヒューリスティッ クであると考えるソニック資本 sonic capitalに言及す る.これはBourdieuのシンボル, 評価, 文化, 経済, 社会資本と並ぶ新しい資本であり，地理学的見地から の視点を反映したものであると考えている，まず，本 発表では空間を, 社会的財と社会的身体の動きと再構 築の過程により社会的に構築されたものであると定 義する。したがって，同氏は空間化 spacingの結果と しての空間に関心を寄せる。同時に，同氏はJames Faulconbridgeの言うように，私達は偶発的過程を扱う のであるのだが，領域の固定化を超えてその先に進む べきであるとの視点をもっている.

次に，ソニック資本は，ヒューリスティックな概念 であり，マイクロな因果関係と技術革新における価值 創造におけるより深い知見を得るための相対的な視点 である，価值創造には文化的および経済的要素が必ず 含まれるという Bourdieuの仮定から始めると，音楽分 野のエージェントはそれらの価值創造を組み合わせ, またその間に予期しない課題に直面すると仮定でき る.この意味において，これらのフォームがどのよう に構成されるかは, 相対的見方においてより主観的で あることは明白であり，これを音楽生産と呼ぶ．音楽 生産では, 文化的価值の生産が経済的価值生産の過程
に先行するか，あるいは付随させる，しかし，音楽生 産は，たとえば産業価值創造とは対照的に，音楽生産 は芸術と類似し，新たなマーケットカテゴリーを生み 出すより広い文化的価值を生み出す。また同時に，そ れは場所と関わり，また变化と偶発性をもたらす。文 化的および経済的価值の創造は, テクノやその他の種 類の電子音楽等の特定の表現領域において相互に関連 しているだけでなく，デジタル化およびヴァーチャル 化の影響下で変化している. 地理学的疑問において は，空間が合成の結果として理解されるのに対し，ソ ニック資本は状況に応じた空間化 situative spacing の結 果として理解できる。これは，本シンポジウム中に紹 介されたコロナ禍における音楽を介在とした共一エン ターテイメント空間の変化とも関連する.

\section{Discussions}

Keynote Lectureに続き, 約 40 分のディスカッショ ンを，主として Lange氏，van Liempt氏，Morgner氏お よび池田の4名で行った。なお，van Liempt氏は既述 の通り, 人文地理学者であり, 夜の研究の先駆者でも ある，近年は，都市の夜の包摂と排除の過程を研究対 象とする，同氏の質問は， (1)ソニック資本と Bourdieu の位置付け，(2)ソニック資本と場所との関係性，(3)地 理学者としての場所の重要性であった。これに対し， Lange氏は，テクノロジーや実践，トランスローカリ ティが重要でありそれを理解するために，文化資本と 経済資本とは異なる資本カテゴリーを創出する必要が あったこと，またBourdieuは，文化・象徴・評価・経 済等の相互接続がどのように機能するかを試すことに 興味があったと考え，技術と芸術的実践と経済学が非 常に混ざり合っている音楽という古典的な分野を試験 的に導入したと述べた。 また，(3に関連しては，地代 の上昇や騒音というより物理的な課題が存在する時, それは場所の問題として出現するが，それに対応する ためのガバナンスという視点において組織が生み出さ れ，あるいは安定化・主流化を避けるための場所の移 動が意図的に存在したことを指摘した。なお，本講義 では理論に続き, ベルリンの事例も紹介された，本稿 では紙面の関係から，今後の議論に重要となる鍵概念 の紹介に焦点を当て要約した。 